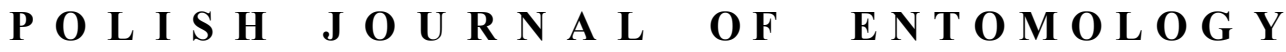

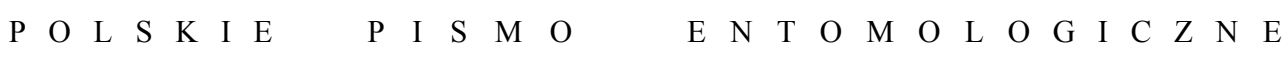

VOL. 82: $233-240$

Gdańsk

31 December 2013

DOI: $10.2478 / \mathrm{v} 10200-012-0038-3$

\section{Bogusław Soszyński}

\author{
ANNA KLASA $^{1} \&$ EWA KRZEMIŃSKA ${ }^{2}$ \\ ${ }^{1}$ Ojców National Park, 32-047 Ojców 9, Poland, e-mail: anna_klasa@wp.pl; \\ ${ }^{2}$ Institute of Systematics and Evolution of Animals, Polish Academy of Sciences, \\ Sławkowska 17, 31-017 Kraków, Poland
}

Bogusław Soszyński was born on 23 December 1947 in Łódź. Already as a child he became very interested in nature, being influenced by his father, a forester and doctor of medicine by education, but who was principally fascinated by nature. He taught his son to identify plants and animals and showed him that nature can be studied. Bogusław spent all his childhood in Łódź, but every summer the family (including his younger brother) used to go for long holidays and explored nature by collecting specimens and through observation. As he now recalls, the entomological net was always lying handy by the door. Bogusław was mostly fascinated by insects, especially flies, but his father warned him that they were "indeterminable".

He graduated in 1965 from the B. Prus High School No. 21 in Łódź, and from 1965 to 1970 studied biology at the Faculty of Biology and Earth Sciences of Łódź University. The subject of his master's degree were the hover flies (Diptera, Syrphidae) of the heaths in the valley of the River Pilica between Sulejów and Tomaszów Mazowiecki. During his studies he was active in the Students' Biological Society, of which he was president in 1968-1969. At that time he cooperated closely with other enthusiastic entomologists in the country, working together in the Polish Scientific Council of the Entomological Sections of Students' Associations of Biologists and Naturalists. In 1968-1973 he organized several biological camps for students in Poland (e.g. in the Bieszczady Mountains and the Roztocze district) and also abroad, for example, to Lake Baikal (1971) and a tour through the European national parks (1973). Years later Prof. Lech Borowiec recalled that they formed "a group of young enthusiastic entomologists from all over Poland". Many of them are now professors at various universities and renowned naturalists, such as the aforementioned Lech Borowiec, Prof. Jarosław Buszko, Prof. Ryszard Szadziewski, Prof. Wiesław Krzemiński, Prof. Stefan Niesiołowski and Dr Lech Krzysztofiak. 


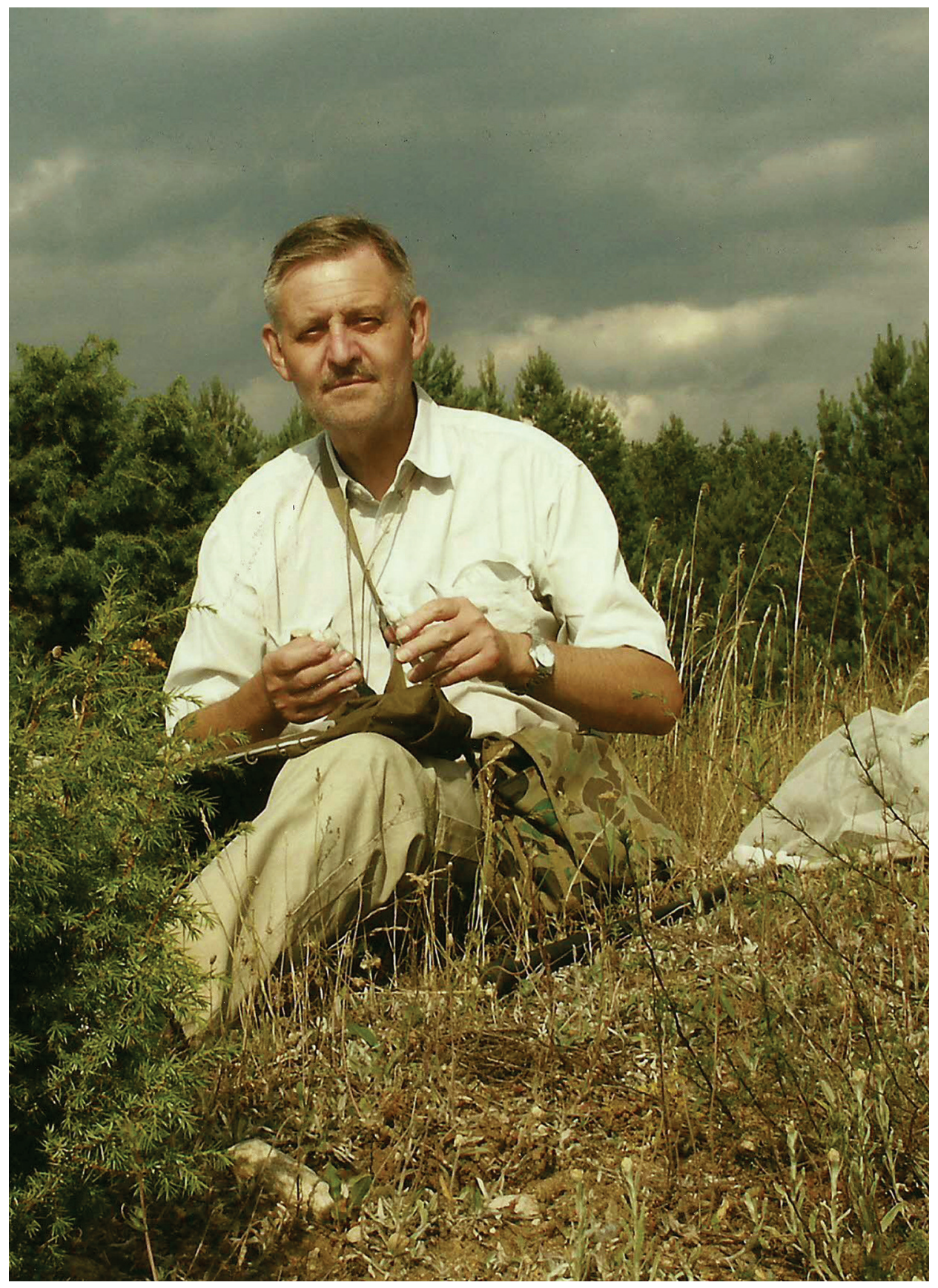

Fig. Bogusław Soszyński in Stanisławów in the Spała Landscape Park, 30 June 2008 (photo: Tadeusz Kurzac). 
After completing the studies he worked as a biology teacher at High School No. 30 in Łódź, and later, in 1973-1978 as an assistant at the SGGW-AR's branch in Rogów. In the 1980s he worked in the research unit of a Pest Control Company in Łódź, and later became director of the Museum of Hunters and Naturalists and Nature Conservation in Piotrków Trybunalski. At this time he was active in the Polish Entomological Society (PTE), first as a board member (1978-1980) and later as president of the Society's branch in Łódź (1978-1986). In 1980, together with Jolanta Wiedeńska, Małgorzata Szadziewska, Adam Burkiewicz, Wiesław Krzemiński, Waldemar Mikołajczyk and Ryszard Szadziewski he founded the Dipterological Section of the PTE. In 1983-1990 and 1996-2000 he was repeatedly elected president of this section.

In the late 1970s he began work on his PhD thesis, which he defended at the Zoological Institute of the Polish Academy of Sciences in Warsaw in 1982. The subject of his thesis was the distribution and origin of the Syrphidae in the Lódź Upland. In the same year he was awarded the Bronze Cross of Merit. In recognition of his services as an animator of entomological activity he was awarded the PTE's Gold Badge in 1986, and a medal for his contribution to the development of PTE in 1998.

In 2006 he was elected a honorary member of the Dipterological Section during its conference in Zawoja. In 2010 he gathered a group of entomologists from various scientific centres and also amateurs interested in Diptera with the aim of organizing a dipterological workshop in Przedbórz. The next workshops also took place in Przedbórz and subsequently at Suche Rzeki in the Bieszczady National Park and were a great success.

In the 1990s Bogusław returned to high school education, teaching ecology and natural history at the Field Centre for Education and Ecology in Łódź, which he founded himself. He also worked for the "Green School" Foundation. From 2000 till his retirement he was also a teacher at High School No. 44 in Łódź.

Bogusław is a skilled organizer. He is constantly in close contact with many dipterologists and is admired for his warm personality. He is always sincerely pleased with the research successes of his friends.

His great dream is to produce, in conjunction with other entomologists, a book on the Polish Syrphidae. This insect family is his great love and these flies he has collected and investigated across the length and breadth of Poland, but with the exception of the high mountains, because he claims to be a "lowland entomologist". Besides his beloved Łódź Upland, he explored mostly the Augustów Forest (1976-1978), the Świętokrzyski National Park (1978-1984), the Borecka Forest, the Białowieża Primeval Forest (1987-1990), the Wigry National Park (1989-1996), the Biebrza National Park (2002-2013) and the Romincka Forest (2005-2006). The only mountain regions he visited were the Bieszczady Mts. (1966-1975) and the Babia Góra Range (1997). During these excursions he accumulated a very large collection of Syrphidae - over 20000 specimens. 
Bogusław is the author of numerous, mostly faunistic papers, on the dipteran families Syrphidae, Conopidae, Coenomyiidae, Tabanidae and Scenopinidae, and also on the Hymenoptera. He has participated in large projects, such as the "Checklists of Animals of Poland" (both editions, 1991 and 2007), the "Red List of Threatened Animals in Poland" (2002), the "Polish Red Data Book of Animals" (2004) and the "Catalogue of Fauna of the Białowieża Primeval Forest" (2001). He has also co-authored large projects on the Diptera of the Bieszczady Mountains, of various landscape parks in the Łódź Upland and on the Syrphidae of the Ojców National Park.

Bogusław is widely admired by his friends as a delightful story teller. He absorbs his listeners in hour-long monologues on various subjects, not only of an entomological nature, but also on geopolitics, current events or literature and the history of Poland, of which he is a keen amateur expert. The aptness of his remarks and comments and associations astonishes, even shocks his listeners - but they are unforgettable! Especially often we recollect the now legendary anecdote about "Vania", which he invented and told off the cuff in order to bring to his senses a hiker we had come across on the Babia Góra mountain. With his stick, this hiker was thrashing the vegetation growing by the track, scaring away if not destroying everything in his path. Bogusław had merely been looking for flies on the plants and this tourist's behaviour annoyed him intensely. He stopped the hiker in his tracks and began to tell the story in his usual slow but irresistible way. The story was about "some Vania" living in Siberia. Every day Vania propped up his dilapidated old door with a huge and heavy boulder. The hiker gradually found out that traveller visited Vania one day and became intrigued by the boulder. He examined it, and it turned out that the boulder was pure gold. "In a second" Vania became the richest man in the village. The moral of the story was that it was knowledge that made Vania rich. If we could examine everything that lived in the vegetation right there, maybe we would discover a medicine for curing cancer, or some other "treasure"? If, on the contrary, we destroy these plants, we are fools like this Vania was. The effect of the story was electrifying. Taken aback and speechless, the hiker threw his stick away, and, having recovered, asked whether he had the honour to be talking with a lawyer, or WHOM?

Our language is the richer for some of Bogusław's expressions, like "the insects are boiling around" (owad się kotłuje), or "hordes of insects" (tabuny owadów) for enormous numbers of some common species, but also for only just three specimens of some rarity; his famous "tossing the corpse" (podrzucanie trupa) for a seemingly favourable but ultimately hopeless situation (when the corpse is tossed it moves but does not come back to life), or newly-coined expressions for vegetation ruined by litter. So, he defined heathland littered with old motor-cars and other rubbish as "Motoroweretum stachytosum" (the two dominant species specified: the motor car and Stachys recta). Bogusław is deeply concerned for the state of nature in Poland and uses his great narrative skills to show its 
beauty and value, as described above. The felling of ancient trees being cut down in the primeval forests of Spała and Białowieża is very painful to him, and likewise the large areas of wilderness being taken over for development. As he says, the "toyoting" of the region is increasing (as everyone drives up to their cottages in their proverbial Toyotas).

Apart from his passion for entomology, Bogusław is interested in numismatics, in philately and in Polish Entomological Society memorabilia. He is very fond of yachting on the Baltic Sea, the Mazurian lakes, Lake Wigry, and in recent years also on the River Biebrza together with his old friends.

On the $50^{\text {th }}$ anniversary of his research and organizational work we wish him success in his efforts to complete his monograph of Polish Syrphidae, and many followers of his activity and consolidation of entomological societies.

\section{List of publications (in chronological order)}

SOSZYŃSKI B. 1968. Interesujące stanowisko biedronki, Coccinella divaricata Oliv. (Coleoptera), koło Łodzi. Notatki Przyrodnicze 2: 2-3.

TrANDA E., Wojciechowski Z., SoSZYŃSKi B. 1969. Notatki ornitologiczne z Bieszczad i Beskidu Niskiego. Zeszyty Naukowe Uniwersytetu Łódzkiego, Nauki Matematyczno-Przyrodnicze, Seria II, 33: 67-70.

WoJTAS F., SOSZYŃSKI B. 1972. Fauna Niebieskich Źródeł - bzygowate (Syrphidae, Diptera). Zeszyty Naukowe Uniwersytetu Łódzkiego, Nauki Matematyczno-Przyrodnicze, Seria II, 46: 75-80.

SosZYŃSKI B., SosZYŃSKI M. 1975. Wyniki badań nad muchówkami z rodziny Bombyliidae, Syrphidae i Conopidae (Diptera) doliny Warty w rejonie Jeziorska. Rozprawy Akademii Rolniczej w Poznaniu, „Jeziorsko 74”- Zeszyt 2, Część II: 76-78.

SOSZYŃSKI B., ŚLIwIŃSKI Z. 1980. Uwagi o entomofaunie rezerwatu Polesie Konstatynowskie. Chrońmy Przyrodę Ojczystą 36: 37-42.

SosZYŃSKI B. 1981. Uwagi na temat fauny Syrphidae (Diptera) Puszczy Augustowskiej. Entomologia, a gospodarka narodowa. PWN, pp.: 119-123.

SoszYŃSKI B. 1981. Geneza Syrphidae (Diptera) Wyżyny Łódzkiej na tle fauny Polski, z uwzględnieniem zespołów tych muchówek w badanych środowiskach. Łódź, 110 pp. (maszyn.)

SOSZYŃSKI B. 1985. Spostrzeżenia fenologiczne nad Syrphidae Wyżyny Łódzkiej. XXXVIII Zjazd PTE. Wiadomości Entomologiczne 6: 72-74.

SosZYŃSKi B., SosZYŃSKi M. 1985. Sceliphron destillatorium (Ill.) (Hymenoptera, Sphecidae) w Polsce. Polskie Pismo Entomologiczne 55: 213-215.

SosZYŃSKI B. 1985. III Sympozjum Sekcji Dipterologicznej Polskiego Towarzystwa Entomologicznego w Łodzi (15-16 III 1984). Wiadomości Entomologiczne 6: 233-235.

SoszYŃSKI B. 1987. IV Sympozjum Sekcji Dipterologicznej Polskiego Towarzystwa Entomologicznego. Spała (14-15 III 1985). Wiadomości Entomologiczne 7: 116-117.

SosZYŃSKI B. 1988. V Sympozjum Sekcji Dipterologicznej Polskiego Towarzystwa Entomologicznego w Mogilanach koło Krakowa (6-7 III 1986). Wiadomości Entomologiczne 8: 96-97. 
SOSZYŃSKI B. 1991. Syrphidae-Conopidae. [In:] RAZOwSKI J. (ed.). Wykaz Zwierząt Polski. Ossolineum Wrocław II, XXXII-28, pp.: 162-170.

SoszYŃSKI B. 1995. Scenopinus niger (DE GEeR, 1776) (Scenopinidae, Diptera) z Lasu Łagiewnickiego w Łodzi. Biuletyn Entomologiczny, Łódź 3/2: 1.

SoszYŃSKI B. 1995. Orthonevra plumbago (LoEw, 1840) (Syrphidae, Diptera) z rezerwatu „Piskorzeniec“w Przedborskim Parku Krajobrazowym. Biuletyn Entomologiczny, Łódź 3/3: 3.

SoszyŃsKi B. 1995. Coenomyia ferruginea (SCOPOLI, 1763) (Coenomyiidae, Diptera) w Lesie Łagiewnickim w Łodzi. Biuletyn Entomologiczny, Łódź 3/5: 2.

SoszYŃSKI B. 1996. Syrphidae Aquatica - wodne bzygowate (Syrphidae: Diptera) Polski. Biuletyn Entomologiczny, Łódź 4/1: 1-5.

SoszYŃSKi B., ŚLIWIŃSKi Z. 1998. Świat zwierząt. Owady. [In:] WnUk Z. (ed.). Przedborski Park Krajobrazowy, Zespół Nadpilicznych Parków Krajobrazowych, pp.: 111-119.

KowalCZyK J.K., MajeCKi J., SosZYŃSKi B., ŚliwińsKi Z. 1998. Fauna bezkręgowców. [In:] KUROWSKI J.K. (ed.). Park Krajobrazowy Wzniesień Łódzkich. Eko-Wynik, Łódź, pp.: 81-88.

SoszyŃSKi B., ŚlıwiŃsKi J., KuRZAwA J. 1998. Fauna. Bezkręgowce. [In:] KuRowsKi J.K. (ed.). Sulejowski Park Krajobrazowy. Wydawnictwo Zespołu Sulejowskich Parków Krajobrazowych, Moszczenica, pp.: 83-90.

Markowski J., Wojciechowski Z., KowALCZYK J. K., TrANDA E., ŚlIWIŃSKi Z., SOSZYŃSKi B. 1998. Fauna Łodzi. Fundacja „Człowiek i Środowisko”, Łódź, 100 pp.

SoszyŃsKi B. 1999. Nowe dla Puszczy Białowieskiej gatunki Syrphidae (Diptera). Parki Narodowe i Rezerwaty Przyrody 18: 117-122.

SOSZYŃSKI B. 1999. Syrphidae saproksylobiontica - bzygowate saprofagi lądowe Polski (Diptera: Syrphidae). Dipteron 15: 30-33.

SOSZYŃSKi B., PALACZYK A., KRZEMIŃSKI W. 2000. Zagrożenia i perspektywy ochrony muchówek (Diptera) w Polsce. Wiadomości Entomologiczne 18, supl. 2: 165-176.

Klasa A., PalaczyK A., SoszyŃSki B. 2000. Muchówki (Diptera) Bieszczadów. Monografie Bieszczadzkie 8: 305-369.

PisArska R., Soszyński B. 2001. Syrphidae - bzygowate. [In:] Gutowski J.M., Jaroszewicz B. (eds.). Katalog fauny Puszczy Białowieskiej. IBL, pp.: 290-292.

Kowalczyk J.K., SoszyŃski B., Majecki J., GrZybKowska M. 2002. Propozycja kompleksowej metody waloryzacji entomofauny w Parku Krajobrazowym Wzniesień Łódzkich. [In:] KUROwSKI J.K., WitosŁawski P. (eds). Funkcjonowanie Parków Krajobrazowych. Katedra Geobotaniki i Ekologii Roślin, Uniwersytet Łódzki, Łódź, pp.: 134-140.

Palaczyk A., Soszyński B., Klasa A., Bystrowski C., MikoŁajczyk W., Krzemiński W. 2002. Diptera - Muchówki. [In:] GŁOWACIŃSKI Z. (ed.). Czerwona lista zwierząt ginących i zagrożonych w Polsce. Instytut Ochrony Przyrody PAN, Kraków, pp.: 38-44.

PalaczyK A., Soszyński B., Klasa A., Bystrowski C., MikoŁajczyK W., KrZemińsKi W. 2002. Diptera Muchówki. [In:] GŁowACIŃSKI Z. (ed.). Czerwona lista zwierząt ginących i zagrożonych w Polsce. Instytut Ochrony Przyrody PAN, Kraków, supl., 77 pp.

SosZYŃSKI B. 2003. Syrphidae (Diptera) Nadmorskiego Parku Krajobrazowego - aktualny stan badań. Dipteron 19: 30-32.

SoszyŃSKi B. 2004. Brachymyia floccosa (MEIGEN, 1822), Caliprobola speciosa (Rossi, 1790), Criorchina pachymera EGGER, 1858, Pocota personata (HARRIS, 1780), Sphecomyia vittata (Wiedemann, 1830). [In:] GŁowACIŃSKi Z., NowACKi J. (eds.). Polska czerwona księga zwierząt. Bezkręgowce. Instytut Ochrony Przyrody PAN, Akademia Rolnicza im. A. Cieszkowskiego, pp.: 302-308. 
SOSZYŃSKi B. 2004. Bąki (Diptera: Tabanidae) Wyżyny Łódzkiej. Dipteron 20: 23-24.

SOSZYŃSKI B. 2005. Syrphidae (Diptera) Biebrzańskiego Parku Narodowego - aktualny stan badań. Dipteron 21: 35-36.

NiESIOŁOWSKI S., SosZYŃSKI B. 2005. Potwierdzenie występowania Syneches muscarius (FABRICIUS, 1794) (Diptera, Hybotidae) w Polsce. Dipteron 21: 28-29.

SoszyŃSKI B. 2007. Bzygowate (Syrphidae) i wyślepkowate (Conopidae). [In:] BogdANOwicz W., Chudzicka E., Pilipiuk I., Skibińska E. (eds). Fauna Polski. Charakterystyka i wykaz gatunków. MiIZ PAN, Warszawa. pp.: 102-106, 193-198.

SoszYŃSKi B., SoszYŃSKA-MAJ A., KLASA A. 2007. Zmiana statusu Chalcosyrphus eunotus (LoEW, 1873) (Diptera: Syrphidae) w Polsce. Dipteron 23: 60-61.

SoszyŃSKi B., KowalczyK J.K., MielcZAReK Ł, Mocarski Z., Osicki T., SobczyK S. 2008. Świat zwierząt. Owady. [In:] WNuk Z. (ed.). Przedborski Park Krajobrazowy. 20 lat istnienia PPK (1988-2008). Wydawnictwo Uniwersytetu Rzeszowskiego, Rzeszów, pp.: 140-153.

KowAlCZYK J.K., SoszYŃSKi B., GALIŃSKA E., KuRZAC T. 2008. Materiały do znajomości żądłówek (Hymenoptera, Aculeata) Spalskiego Parku Krajobrazowego i terenów przyległych. Parki Narodowe i Rezerwaty Przyrody 27: 51-62.

SOSZYŃSKA-MAJ A., SosZYŃSKi B., KLASA A. 2009. Distribution and ecology of the saproxylic hoverfly Chalcosyrphus eunotus (LoEw, 1873) (Diptera: Syrphidae) in Poland. Fragmenta Faunistica 52: 191-195.

KowAlCZYK K., KurZaC T., SosZYŃSKi B. 2009. Porobnica paskowana Anegilla quadrifasciata (VILLERS, 1789) - nowe stanowisko nowej polilektycznej pszczoły w Polsce. Chrońmy Przyrodę Ojczystą 65: 231-233.

KowalczyK J.K., KurZaC T., SoszyŃSKi B. 2009. Nowe stanowiska interesujących gatunków żądłówek (Hymenoptera, Aculeata) w regionie łódzkim. Parki Narodowe i Rezerwaty Przyrody 28: $127-134$.

KLASA A., SoszyŃSKI B. 2010. Dziewięć nowych dla Polski gatunków muchówek z rodziny bzygowatych (Diptera: Syrphidae) z Ojcowskiego Parku Narodowego i innych regionów kraju. Wiadomości Entomologiczne 29: 302-304.

SOSZYŃSKI B., SOSZYŃSKA-MAJ A., KowALCZYK J.K. 2010. Bzygowate - Syrphidae. [In:] JASKUŁA R., ToŃCZYK G. (eds). Owady (Insecta) Parku Krajobrazowego Wzniesień Łódzkich. Dyrekcja Parku Krajobrazowego Wzniesień Łódzkich / Mazowiecko-Świętokrzyskie Towarzystwo Ornitologiczne, Łódź, pp.: 157-158.

Soszyński B., Soszyńska-Maj A., Palaczyk A., Kowalczyk J.K., Bystrowski C, Durska E., WoźNICA A. 2010. Wybrane rodziny muchówek (Diptera) za wyjątkiem Limoniidae, Pediciidae, Chironomidae, Empidoidea i Syrphidae. [In:] JASKUŁA R., ToŃCZYK G. (eds). Owady (Insecta) Parku Krajobrazowego Wzniesień Łódzkich. Dyrekcja Parku Krajobrazowego Wzniesień Łódzkich / Mazowiecko-Świętokrzyskie Towarzystwo Ornitologiczne, Łódź, pp.: 165-185.

SOSZYŃSKI B., SosZYŃSKA-MAJ A. 2011. The significance of the Lublinek Range for preserving diversity of hoverflies (Diptera: Syrphidae) in Łódź (Poland). [In:] INDYKIEWICz P., JERZAK L., Böchner J., KAVANAGH B. (eds). Urban fauna. Studies of animal biology, ecology and conservation in European cities. UTP, Bydgoszcz, pp.: 277-286.

Klasa A., Kaczorowska E., SoszyńSKi B. 2011. Fruit flies (Diptera: Tephritidae) of the Polish Baltic Coast. Polish Journal of Entomology 80: 555-578.

KlASA A., SoszyŃSKI B. 2011. Bzygowate (Syrphidae: Diptera) Ojcowskiego Parku Narodowego (Polska południowa). Parki narodowe i Rezerwaty Przyrody 30: 61-102. 
SosZYŃSKI B., SosZYŃSKA-MAJ A. 2011. Hoverflies (Diptera: Syrphidae) of Polesie Konstantynowskie Nature Reserve with reference to the Syrphidae fauna in Łódź (Poland) [In:] InDYKIEWICZ P., JERZAK L., Böchner J., KAVANAGH B. (eds). Urban fauna. Studies of animal biology, ecology and conservation in European cities. UTP, Bydgoszcz, pp.: 287-295.

Received: 30 October 2013

Accepted: 7 November 2013 